\title{
BEBERAPA FAKTOR YANG BERHUBUNGAN DENGAN KEAKTIFAN KADER POSYANDU DI DESA PENGADEGAN KABUPATEN BANYUMAS
}

\section{Factors Associated with the Activeness of Cadres in Maternal and Baby Clinic of Pengadegan Village Banyumas District}

\author{
Arina Candra Profita \\ Ikatan Bidan Indonesia Banyumas, Indonesia \\ E-mail: arynacandra@gmail.com
}

\begin{abstract}
Background: Posyandu is a maternal and baby clinic to decline the infant mortality rate, infant birth rate, and maternal mortality. The success of activities in Posyandu depends on the cadre's activeness. Data obtained from Banyumas district office in 2013 showed that Puskesmas 1 Wangon hads the lowest percentage of active cadres in Banyumas district, especially posyandu in Pengadegan Village (36 cadres) (60\%).

Aim: This research aimed at identifying some factors related to the activity of cadres in Posyandu of Pengadegan Village, Banyumas Disctrict.

Method: This study used an analytic survey method with total sampling of 60 cadres. The independent variables of this research are knowledge, occupation, motivation and government's support while the activeness of cadres is as a dependent variable. The research instruments were questionnaire and cadre attendance document. Data were analyzed descriptively by using Chi Square.

Results: The result shows that knowledge, work, motivation and support of Posyandu are related to the activity of cadres in Posyandu of Pengadegan Village, Banyumas Disctrict. Cadres' high activeness is influenced by good knowledge about maternal and baby clinic, high motivation, and unemployement.

Conclusion: Knowledge, job, motivation and support from other stakeholders are needed to encourage cadres participation in the maternal and baby clinic. Coaching and refreshing cadres on an ongoing basis and giving them an award can be alternatives to improve their active participation.
\end{abstract}

Keywords: activeness, cadre, Posyandu

\section{ABSTRAK}

Latar Belakang: Posyandu merupakan klinik ibu dan anak untuk mempercepat penurunan angka kematian bayi, angka kelahiran bayi, dan angka kematian ibu. Keberhasilan kegiatan posyandu tergantung pada peran aktif kader. Data Dinas Kabupaten Banyumas tahun 2013 mengatakan bahwa persentase kader aktif di wilayah Puskesmas I Wangon merupakan yang paling rendah di Kabupaten Banyumas khususnya pada posyandu di Desa Pengadegan yaitu 36 kader (60\%).

Tujuan: Tujuan penelitian ini adalah untuk mengidentifikasi beberapa faktor yang berhubungan dengan keaktifan kader posyandu di Desa Pengadegan Kabupaten Banyumas.

Metode: Penelitian ini menggunakan metode survey analitik dengan total sampling sebanyak 60 kader. Variabel bebas penelitian ini adalah pengetahuan, pekerjaan, motivasi dan dukungan pemerintah sedangkan keaktifan kader posyandu sebagai variabel terikat. Instrumen penelitian ini adalah kuesioner dan dokumen kehadiran Kader Posyandu. Data dianalisis secara deskriptif menggunakan Chi Square.

Hasil: Hasil dari penelitian ini menunjukan bahwa pengetahuan, pekerjaan, motivasi dan dukungan penyelenggaraan posyandu berhubungan dengan keaktifan Kader posyandu di Desa Pengadegan Kabupaten Banyumas. Tingkat keaktifan yang tinggi dipengaruhi oleh pengetahuan yang baik tentang posyandu, motivasi yang tinggi, dan tidak bekerjanya kader tersebut.

Kesimpulan: Pengetahuan, motivasi, dan dukungan dari berbagai pihak dibutuhkan untuk mendorong kader untuk aktif di posyandu. Pembinaan dan refreshing kader secara berkesinambungan dan memberikan penghargaan pada kader dapat menjadi alternatif untuk meningkatkan partisipasi aktif mereka.

Kata Kunci: kader,keaktifan, Posyandu

\section{PENDAHULUAN}

Posyandu adalah ujung tombak pelayanan kesehatan yang memiliki tujuan untuk mempercepat upaya penurunan Angka Kematian Bayi (Infant
Mortality Rate), Angka Kelahiran Bayi (Birth Rate), Angka Kematian Ibu (Maternal Mortality Rate). Ada berbagai kegiatan yang dilaksanakan di posyandu yaitu kegiatan pemantauan tumbuh kembang balita, pelayanan kesehatan ibu dan anak termasuk 
pemberian imunisasi guna pencegahan penyakit, penanggulangan kejadian diare, pelayanan $\mathrm{KB}$, penyuluhan dan konseling/rujukan konseling apabila dibutuhkan.

Dengan adanya pelaksanaan kegiatan pada pPosyandu diharapkan dapat membantu untuk meningkatkan derajat kesehatan masyarakat di Indonesia. Pembentukan posyandu di tingkat desa dalam 25 tahun terakhir memberikan kontribusi pula pada penurunan jumlah kematian bayi dan anak di Indonesia. Posyandu menyediakan perawatan kesehatan khusus bagi ibu dan anak serta diadakannya berbagai program kesehatan dasar termasuk keluarga berencana, gizi, dan imunisasi.

Penyebaran posyandu di Indonesia masih belum diiringi dengan kualitas pelayanan yang baik. Peran kader dan partisipasi masyarakat sangat diperlukan. Penyelenggaraan upaya kesehatan dari, oleh, dan untuk masyarakat yang ada di posyandu Desa Pengadegan masih belum sesuai. Kehadiran petugas kesehatan di meja ke empat dalam Penyuluhan posyandu belum maksimal karena kurangnya peran kader yang seharusnya bisa menangani pelayanan pada meja tersebut.

Tugas untuk perencanaan berbagai kegiatan yang ada pada posyandu, pelaksanaan, evaluasi dan pengendalikan kegiatan posyandu, serta pelaporkan kegiatan posyandu dilakukan oleh kader posyandu (Departemen Kesehatan RI, 2011). Melihat dari tugas kader posyandu tersebut sudah dapat disimpulkan bahwa posyandu akan terlaksana dengan maksimal apabila para kader posyandu aktif dalam pelaksanaan posyandu. Hal tersebut dikarenakan kader dapat menjadi motivator yang tepat untuk membantu mewujudkan kesehatan ibu dan anak.

Kader memiliki peran besar terhadap lancarnya proses pelayanan kesehatan salah satunya kegiatan posyandu. Namun, beberapa hal dapat menjadi penyebab keberadaan kader menjadi labil. Labilnya keberadaan kader ini disebabkan oleh partisipasi kader yang bersifat sukarela sehingga tidak menjamin bahwa kader akan tetap menjalankan fungsinya dengan baik. Kondisi ekonomi yang tidak stabil juga menyebabkan banyak kader yang aktif menjadi tidak aktif bahkan menjadi drop out. Menurunnya kinerja kader posyandu antara lain dikarenakan oleh gangguan ekonomi, kejenuhan kader karena kegiatan yang rutin dan kurangnya perhatian pemerintah setempat dalam mendukung pelaksanaan kegiatan di posyandu.

Terdapat 3 faktor yang dapat mempengaruhi perilaku. Perilaku tersebut dalam hal ini dapat berupa keaktifan kader. Beberapa faktor tersebut yaitu berbagai faktor predisposisi (predisposing factors), faktor pemungkin (enabling factors), dan faktor penguat (reinforcing factors).Yang termasuk dalam faktor predisposisi misalnya adalah tingkat pengetahuan, tingkat pendidikan, status pekerjaan, motivasi, sikap, nilai budaya, kepercayaan serta kondisi dari sosial ekonomi kader. Perilaku yang didasari dengan adanya pengetahuan diketahui dapat menjadi lebih langgeng daripada perilaku yang tidak didasari oleh pengetahuan, sedangkan untuk faktor pendukung berupa lingkungan fisik dan ketersediaan sarana dan prasarana yang dapat mendukung kelancaran dari pelaksanaan Posyandu. Faktor pendorong antara lain dapat berupa dukungan dari tokoh masyarakat, keluarga, dan dari pemerintah serta sikap dari petugas kesehatan (Notoatmodjo, 2014). Menurut Wirapuspita (2013) faktor yang berhubungan dengan kinerja kader adalah berupa pemberian bantuan operasional, piagam, uang, transport serta pelatihan dari berbagai pihak dalam hal ini yaitu pemerintah dan masyarakat setempat.

Menurut data Dinas Kesehatan Kabupaten Banyumas, terdapat 12.613 kader posyandu di wilayah Kabupaten Banyumas. Namun, hanya terdapat kader aktif sebanyak 11.900 orang (94\%). Pada hampir semua wilayah puskesmas di Kabupaten Banyumas, persentase kader yang aktif sudah lebih dari $90 \%$ bahkan banyak yang sudah mencapai 100\%. Akan tetapi berbeda dengan kondisi yang ada di wilayah Puskesmas I Wangon, persentase kader aktif di wilayah Puskesmas I Wangon masih rendah dibandingkan dengan wilayah kerja Puskesmas lainnya di Kabupaten Banyumas (Dinas Kesehatan Kabupaten Banyumas, 2013).

Hingga akhir tahun 2013 tecatat setidaknya terdapat 78 unit posyandu pada wilayah kerja Puskesmas I Wangon. Total kader posyandu tercatat sebanyak 353 orang namun hanya $81 \%$ saja yang merupakan kader aktif. Kader ini tersebar pada tujuh desa yang ada di wilayah kerja Puskesmas I Wangon. Desa Pengadegan merupakan desa dengan tingkat partisipasi kader aktif yang paling rendah. Penelitian ini bertujuan untuk mengidentifikasi faktor yang berhubungan dengan keaktifan kader posyandu Desa Pengadegan Wilayah Kerja Puskesmas 1 Wangon.

\section{METODE}

Penelitian dilakukan selama 3 bulan yaitu pada bulan Maret sampai dengan Mei 2014 di Desa Pengadegan Wilayah Kerja Puskesmas 1 Wangon. Desa ini merupakan desa dengan tingkat keaktifan kader posyandu terendah di wilayah kerja Puskesmas I Wangon. Penelitian ini menggunakan pendekatan cross sectional. Instrumen yang digunakan pada penelitian ini adalah kuesioner serta dilengkapi dengan data sekunder berupa daftar kehadiran kader posyandu. Populasi dalam penelitian ini ialah semua kader posyandu yang ada di Desa Pengadegan sebanyak 60 orang. Pengambilan besar sampel penelitian menggunakan total sampling.

Uji validitas kuessioner pada penelitian ini menggunakan teknik korelasi Product Moment yang dilakukan pada 20 responden yang merupakan kader posyandu pada desa lain dengan karakteristik responden yang sama dengan kader posyandu di Desa Pengadegan. Uji validitas dan reliabilitas menunjukkan kuesioner valid dan reliabel.

Data primer diambil melalui wawancara menggunakan kuesioner dengan skala likert yang dibagikan ke setiap kader posyandu. Keaktifan bidan diidentifikasi berdasarkan daftar hadir kader di 
setiap posyandu di Desa Pengadegan Kabupaten Banyumas.

Analisis statistik yang digunakan dalam penelitian ini adalah analisis univariat dan analisis bivariat. Analisis univariat yang dilakukan yaitu data hasil penelitian ditabulasi untuk dianalisis dengan cara menghitung nilai mean, dan persentase. Data dianalisis menggunakan analisis bivariat dengan Chi-Square.

\section{HASIL DAN PEMBAHASAN}

Hasil penelitian menunjukkan dari 60 orang kader posyandu di Desa Pengadegan wilayah kerja Puskesmas I Wangon, jumlah kader yang aktif hadir dalam pelaksanaan posyandu adalah sebanyak 36 kader $(60 \%)$, sedangkan yang tidak aktif sebanyak 24 kader (40\%). Berdasarkan hasil tersebut dapat diketahui bahwa jumlah kader yang aktif lebih banyak dibanding yang tidak aktif, tetapi jika dilihat kembali dan dihitung berdasarkan jumlah posyandu yang ada di Desa Pengadegan tingkat keaktifan kader masih kurang, hal tersebut dapat diketahui dengan jumlah rata-rata kehadiran kader posyandu yang aktif (hadir $\geq 8$ kali/tahun) masih kurang dari 5 kader di setiap posyandu yang ada, sedangkan kader yang aktif adalah kader yang selalu datang ke kegiatan posyandu, dan posyandu yang baik adalah posyandu yang diselenggarakan $\geq 8$ kali/tahun (Departemen Kesehatan RI, 2011).

Keaktifan kader merupakan keikutsertaan kader dalam kegiatan kemasyarakatan yang merupakan usaha untuk memenuhi berbagai kebutuhan yang dirasakan masyarakat dan pengabdian terhadap tugasnya sebagai kader. Keaktifan kader posyandu tersebut dapat dilihat dari ada atau tidaknya kegiatan posyandu sebagai tugas dan tanggung jawab yang diberikan padanya, kegiatan tersebut juga akan berjalan dengan baik bila didukung oleh fasilitas yang memadai. Fasilitas yang disediakan tersebut hendaknya harus cukup dan sesuai dengan tugas dan fungsi yang dilaksanakan serta ketersediaan waktu, tempat yang sesuai, dan layak untuk menunjang kegiatan posyandu (Departemen Kesehatan RI, 2011).

Kemampuan kader untuk menggerakkan masyarakat akan mempengaruhi partisipasi ibu balita yang datang di posyandu. Peran kader dalam penyelenggaraan posyandu sangat besar karena selain sebagai pemberi informasi kesehatan kepada masyarakat juga sebagai penggerak masyarakat untuk datang ke posyandu dan melaksanakan Perilaku Hidup Bersih Dan Sehat (Departemen Kesehatan RI, 2011). Maka dari itu keaktifan kader dalam hal ini kehadiran kader dalam pelaksanaan Posyandu sangat penting untuk tercapaian tujuan dari Poyandu sendiri.

Hasil penelitian menunjukkan dari 60 kader di Desa Pengadegan wilayah kerja Puskesmas I Wangon ada 26 kader (43,33\%) memiliki pengetahuan yang baik tentang Posyandu, kader yang pengetahuannya cukup ada sebanyak 19 kader $(31,67 \%)$ dan kader yang pengetahuannya kurang hanya ada sebanyak 15 kader (25\%). Hal ini menunjukkan sebagian besar kader di Desa Pengadegan wilayah kerja Puskesmas I Wangon memiliki pengetahuan yang baik tentang Posyandu.
Pengetahuan mempengaruhi pendidikan dan perilaku seseorang (Notoatmodjo, 2014). Kader diharapkan memiliki tingkat pengetahuan yang baik mengenai tujuan dan manfaat posyandu sehingga sikap kader tersebut akan mendukung motivasi yang tinggi untuk aktif dalam kegiatan posyandu (Sistiriani, et al., 2013). Menurut penelitian yang dilakukan Suhat \& Hasanah (2014) kader yang mempunyai pengetahuan baik dan cukup tentang Posyandu akan aktif dalam kegiatan posyandu karena kader mengetahui tentang manfaat Posyandu. Kader yang mempunyai pengetahuan rendah biasanya kurang atau tidak mengetahui manfaat posyandu sehingga mereka tidak aktif di kegiatan posyandu. Tingkat pengetahuan mengenai posyandu merupakan salah satu faktor yang dapat mempengaruhi keaktifan kader (N. Legi, et al., 2015).

Teori dan beberapa hasil dari penelitian tersebut sejalan dengan hasil penelitian ini yang menunjukan bahwa kader yang memiliki tingkat pengetahuan baik mengenai hal yang berkaitan dengan poyandu persentase keaktifan kader lebih besar yaitu sebanyak 22 kader (84,6\%) dibandingkan dengan persentase kader yang pengetahuannya cukup yaitu sebanyak 10 kader $(52,6 \%)$. Kader dengan pengetahuan yang kurang memiliki persentase keaktifan kader yang paling rendah yaitu sebanyak 4 kader $(26,7 \%)$. Pada penelitian ini pada umumnya kader telah memiliki pengetahuan yang baik mengenai tujuan dan manfaat posyandu namun untuk pengetahuan mengenai tata cara pelaksanaan posyandu yang tepat mengenai 5 meja posyandu dan urutan pelaksanaan yang tepat serta pengetahuan mengenai tugas kader masih rendah.

Sebanyak 60 orang kader Posyandu di Desa Pengadegan wilayah kerja Puskesmas I Wangon sebanyak 35 kader $(58,33 \%)$ berstatus bekerja, dan 25 kader $(41,67 \%)$. Kader lainnya tidak bekerja. Sebagian besar kader Posyandu Desa Pengadegan memiliki pekerjaan utama, selain menjadi kader.

Hasil penelitian ini memperlihatkan bahwa kader yang bekerja lebih kecil persentase keaktifan kadernya yaitu sebanyak 14 kader (40\%) dibandingkan dengan persentase keaktifan kader yang tidak bekerja yaitu sebanyak 22 kader (88\%). Hasil penelitian ini sesuai dengan penelitian lain yang menyebutkan bahwa kader posyandu yang aktif sebagian besar tidak bekerja (Suhat \& Hasanah, 2014).

Setelah dilakukan pengukuran terhadap motivasi kader ternyata dari 60 kader di Desa Pengadegan wilayah kerja Puskesmas I Wangon ada 41 kader $(68,33 \%)$ yang memiliki motivasi tinggi untuk aktif di kegiatan Posyandu. Kader Posyandu yang motivasinya cukup ada sebanyak 10 kader $(16,67 \%)$ dan kader yang motivasinya kurang adalah 9 kader (15\%). Sebagian besar kader di Desa Pengadegan wilayah kerja Puskesmas I Wangon memiliki motivasi yang tinggi untuk aktif di kegiatan posyandu. Motivasi yang tinggi tersebut terlihat dari jawaban kader yang menjawab bahwa mereka senang dan sukarela menjadi kader posyandu serta pernyataan semangatnya dalam mengikuti kegiatan Posyandu karena mereka setuju 
bahwa posyandu itu sangat penting untuk memajukan kesehatan di masyarakat.

Hasil penelitian ini selaras dengan hasil penelitian yang dilakukan oleh Husniyawati (2016) bahwa kader yang aktif cenderung mempunyai motivasi tinggi untuk memajukan posyandu. Penelitian ini juga sejalan dengan penelitian Ilham, et al., (2013) yang dilakukan di posyandu Wilayah Kerja Puskesmas Lisu Kecamatan Tanete Riaja Kabupaten Barru yang menyebutkan bahwa kader yang kinerjanya tinggi juga memiliki motivasi tinggi.

Hasil penelitian menunjukkan dari 60 orang kader Posyandu di Desa Pengadegan wilayah kerja Puskesmas I Wangon, ada sebanyak 43 kader (71,67\%) yang mendapat berbagai dukungan dari penyelenggaraan Posyandu sedangkan yang tidak mendapat dukungan sebanyak 17 kader (28,33\%). Hal ini menunjukkan bahwa sebagian besar kader di Desa Pengadegan mendapatkan dukungan dari penyelenggaraan posyandu. Dukungan terbesar yang dirasakan oleh kader adalah berupa sarana dan prasarana kegiatan posyandu yang diberikan oleh pemerintah.

Dukungan penyelenggaraan posyandu yang diberikan kepada kader dapat berupa dukungan material, bantuan dana, tempat penyelenggaraan, serta peralatan posyandu (Departemen Kesehatan RI, 2011). Dukungan tersebut salah satunya berasal dari pemerintah dan masyarakat setempat. Kader yang mendapat dukungan dari pemerintah dan masyarakat akan aktif di kegiatan posyandu. Dukungan yang diberikan kepada kader akan membangkitkan motivasi dan meningkatkan semangat kader posyandu untuk aktif di kegiatan posyandu.

Hasil penelitian menunjukkan bahwa dari 15 kader dengan pengetahuan kurang terdapat 4 kader $(26,7 \%)$ yang aktif dan 11 kader $(73,3 \%)$ yang tidak aktif. Sedangkan, dari 19 kader dengan pengetahuan cukup terdapat 10 kader $(52,6 \%)$ yang aktif dan 9 kader $(47,4 \%)$ yang tidak aktif. Pada 26 kader dengan pengetahuan baik, terdapat 22 kader $(84,6 \%)$ yang aktif dan 4 kader $(15,4 \%)$ yang tidak aktif. Hasil tersebut menunjukan bahwa yang memiliki persentase kader aktif paling tinggi adalah kader yang pengetahuannya baik, yaitu $84,6 \%$

Perhitungan menunjukkan nilai $\mathrm{X}^{2}$ hitung 13,938 menghasilkan nilai $P$-value 0,000 . Nilai ini menunjukkan hubungan yang signifikan antara pengetahuan dengan keaktifan. Pengujian coefficient contingency menunjukkan nilai 0,434 artinya hubungan antara pengetahuan dengan keaktifan kader dalam kategori sedang. Hasil penelitian menunjukkan terdapat hubungan antara pengetahuan dengan keaktifan kader posyandu di Desa Pengadegan wilayah kerja Puskesmas I Wangon. Hal ini dapat dilihat dari nilai $X^{2}$ hitung (ChiSquare) yang dihasilkan sebesar 13,938 yang berarti $X^{2}$ hitung $>X^{2}$ tabel. Nilai $P$-value sebesar 0,000 . Berdasarkan hasil perhitungan tersebut menunjukkan nilai $P$-value $<\alpha 0,05$, yang berarti secara statistik terdapat hubungan antara pengetahuan dengan keaktifan kader Posyandu dengan nilai contingency coefficient yang dihasilkan sebesar 0,434 artinya hubungan antara pengetahuan dengan keaktifan kader dalam kategori sedang.

Kader kesehatan yang memiliki pengetahuan baik tentang posyandu akan aktif mengikuti kegiatan posyandu begitu juga sebaliknya. Kader yang mempunyai pengetahuan baik dan cukup tentang posyandu akan aktif karena mereka mengetahui tentang manfaat posyandu dan tujuan posyandu. Kurangnya pengetahuan pada kader posyandu disebabkan karena informasi yang didapat tentang perkembangan posyandu masih kurang. Pembinaan yang rutin dari petugas kesehatan belum maksimal, dan sedikitnya penghargaan untuk kader teladan dan berprestasi.

Tingkat pengetahuan adalah salah satu faktor yang mempengaruhi tingkat keaktifan kader posyandu. Dalam domain pengetahuan, pengertian dari sebuah pengetahuan merupakan bagian yang pertama dari tingkatan pengetahuan. Pengertian atau tahu merupakan awal untuk mengetahui segala sesuatu. Hal ini menyebabkan pengertian atau tahu merupakan bagian yang utama dalam tingkatan pengetahuan walaupun tingkatan paling rendah dalam pengetahuan.

Pengetahuan ialah bagian penting untuk proses pembentukkan perilaku seseorang (Notoatmodjo, 2014). Tingkat pengetahuan kader mengenai posyandu dapat mempengaruhi secara langsung maupun tidak langsung terhadap perilaku serta kepatuhan kader untuk mendukung pelaksanaan program yang ada pada posyandu.

Hasil penelitian sesuai penelitian Happinasari \& Suryandari (2016) yang menjelaskan bahwa pengetahuan merupakan salah satu faktor yang berhubungan dengan keaktifan kader posyandu. Hasil penelitian ini juga selaras dengan hasil penelitian Suhat \& Hasanah (2014) yang menyatakan bahwa ada hubungan antara pengetahuan dengan keaktifan kader kesehatan.

\section{Hubungan Pekerjaan Kader dengan Keaktifan Kader Posyandu}

Berdasarkan hasil penelitian pada 35 kader yang bekerja terdapat 14 kader $(40,0 \%)$ yang aktif dan 21 kader $(60,0 \%)$ yang tidak aktif dalam posyandu, sedangkan dari 25 kader yang tidak bekerja terdapat 22 kader $(88,0 \%)$ yang aktif dan 3 kader $(12,0 \%)$ yang tidak aktif. Hal tersebut menunjukan bahwa persentase kader aktif tertinggi adalah kader yang tidak bekerja.

Hasil penelitian menunjukkan terdapat hubungan antara pekerjaan dengan keaktifan kader posyandu di Desa Pengadegan wilayah kerja Puskesmas I Wangon. Hal ini dapat dilihat dari nilai $X^{2}$ hitung (Chi-Square) yang dihasilkan sebesar 14,000 yang berarti $X^{2}$ hitung $>X^{2}$ tabel. Nilai $P$-value sebesar 0,000 , yang berarti nilai $P$-value $<\alpha \quad 0,05$. Berdasarkan hasil tersebut dapat disimpulkan secara statistik terdapat hubungan antara pekerjaan dengan keaktifan kader posyandu dengan nilai contingency coefficient yang dihasilkan sebesar 0,435 artinya hubungan antara pekerjaan dengan keaktifan kader dalam kategori sedang.

Pada awalnya kader ditunjuk dengan keadaan belum mengetahui apapun atau kurang mengetahui tentang apa yang akan dikerjakan 
tetapi sebagian mereka tidak merasa keberatan, menyesal dan tidak terpaksa. Tugas kader posyandu cukup berat dalam mengelola dan melayani masyarakat, karena posyandu merupakan sarana yang diciptakan dan dikembangkan atas kesadaran dan upaya sendiri atas partisipasi sosial setiap komunitas di desa dan di kota. Disamping sebagi kader tentunya sebagian dari kader juga masih memiliki tanggung jawab lain misalnya dengan status pekerjaan yang diemban.

Pekerjaan kader dapat menjadi salah satu faktor yang berhubungan dan mempengaruhi keaktifan kader. Pekerjaan merupakan suatu kegiatan atau aktivitas seseorang untuk memperoleh penghasilan guna memenuhi kebutuhan hidup setiap harinya. Pekerjaan juga dapat mempengaruhi seseorang terhadap peran serta masyarakat hal tersebut terjadi karena ketersediaan waktu yang dapat digunakan untuk kegiatan sosial. Semakin sedikit waktu seseorang untuk bersosialisasi karena pekerjaannya menyebabkan menurunnya tingkat kesadaran dan tanggung jawab mereka terhadap kegiatan sosial, salah satunya adalah peranan aktif menjadi kader kesehatan di lingkungan.

Hasil penelitian yang menunjukkan bahwa kader posyandu yang tidak bekerja persentase keaktifannya lebih besar dibandingkan dengan yang bekerja dimana orang yang bekerja selaras dengan teori yang menyatakan bahwa orang yang bekerja memiliki kesempatan yang sedikit untuk mengikuti kegiatan sosial dikarenakan kesibukannya.

Hasil penelitian ini juga sesuai dengan Notoatmodjo (2014) yang mengemukakan bahwa pekerjaan merupakan salah satu faktor predisposisi yang mempengaruhi seseorang dalam berperilaku. Hasil penelitian ini juga sejalan dengan hasil penelitian yang dilakukan oleh Suhat \& Hasanah (2014)yang menyatakan ada hubungan antara pekerjaan dengan keaktifan kader di posyandu.

\section{Hubungan Motivasi Kader dengan Keaktifan Kader Posyandu}

Berdasarkan hasil penelitian dari 9 kader yang memiliki motivasi kurang terdapat 2 kader $(22,2 \%)$ yang aktif dan 7 kader $(77,8 \%)$ yang tidak aktif, dari 10 kader dengan motivasi cukup terdapat 2 kader (20,0\%) yang aktif dan 8 kader $(80,0 \%)$ yang tidak aktif, sedangkan dari 41 kader dengan motivasi baik terdapat 9 kader $(22,9 \%)$ yang tidak aktif dan 32 kader $(78,0 \%)$ yang aktif. Hasil tersebut menunjukkan bahwa yang memiliki persentase kader aktif yang paling tinggi adalah kaderdengan motivasi yang baik yaitu $78 \%$

Hasil penelitian menunjukkan terdapat hubungan antara motivasi dengan keaktifan kader posyandu di Desa Pengadegan wilayah kerja Puskesmas I Wangon. Hal ini dapat dilihat dari nilai $X^{2}$ hitung (Chi-Square) yang diperoleh sebesar 17,584 , $X^{2}$ hitung $>X^{2}$ tabel. Nilai $P$-value sebesar 0,000 . yang berarti nilai $P$-value $<\alpha \quad 0,05$. Berdasarkan hasil tersebut dapat disimpulkan secara statistik terdapat hubungan antara motivasi dengan keaktifan kader Posyandu dan nilai contingency coefficient sebesar 0,476 artinya hubungan antara motivasi dengan keaktifan kader dalam kategori sedang.
Dari hasil penelitian ini dapat diketahui bahwa motivasi berhubungan dengan perilaku kader untuk aktif hadir di kegiatan posyandu. Kader yang mempunyai motivasi yang tinggi akan aktif di kegiatan posyandu karena ada dorongan dari dalam diri mereka untuk aktif dan memajukan posyandu. Kader yang mempunyai motivasi kurang cenderung tidak akan aktif karena tidak ada dorongan dari dalam diri mereka untuk aktif dan memajukan posyandu.

Motivasi secara umum berhubungan dengan usaha untuk mencapai tujuan. Tingkat motivasi dari setiap individu dalam suatu organisasi pasti berbeda. Kader sebagai bagian dari sebuah organisasi dalam hal ini posyandu juga memilki tingkat motivasi yang berbeda antara kader satu dengan lainnya. Keberagaman tersebut dapat menimbulkan perbedaan perilaku dalam suatu organisasi. Pada proses motivasi, seseorang berusaha untuk memenuhi berbagai kebutuhan sehingga mendorong seseorang untuk memilih melakukan suatu tindakan agar tujuannya dapat terpenuhi.

Hal yang menjadi kunci dari teori harapan adalah pemahaman dari tujuan individu dan kaitannya antara upaya dan kinerja, antara kinerja dengan imbalan, dan akhirnya imbalan tersebut dapat memuaskan individu (tujuan individu terpenuhi). Hal tersebut mendukung hasil penelitian bahwa tingkat motivasi kader posyandu di Desa Pengadegan Wilayah Kerja Puskesmas I Wangon berhubungan dengan tingkat keaktifannya mengikuti kegiatan posyandu.

Hasil penelitian ini juga sesuai dengan penelitian yang dilakukan oleh Husniyawati (2016)yang menyatakan ada hubungan antara motivasi dengan keaktifan kader posyandu dan kader yang aktif memiliki motivasi yang tinggi untuk memajukan posyandu. Penelitian Prang (2013)juga menunjukkan adanya hubungan atara hubungan yang signifikan antara motivasi kader dengan keaktifan kader. Selain itu pada penelitian Kontesa \& Mistuti (2013) dan Fadli dan Adriani (2013) yang juga menyatakan bahwa ada hubungan kinerja kader posyandu dengan motivasi di Puskesmas Bungoro Kabupaten Pangkep. Hasil penelitian Wijaya, Murti dan Putu (2013) juga menyebutkan bahwa terdapat hubungan yang signifikan antara motibasi terhadap kekatifan kader kesehatan.

\section{Hubungan Dukungan Penyelenggaraan Posyandu dengan Keaktifan Kader Posyandu}

Hasil penelitian menunjukkan bahwa dari 43 kader posyandu yang mendapatkan dukungan penyelenggaraan Posyandu terdapat 32 kader $(74,4 \%)$ yang aktif dan 11 kader $(25,6 \%)$ yang tidak aktif, sedangkan dari 17 kader yang tidak mendapat dukungan penyelenggaraan Posyandu terdapat 4 orang $(23,5 \%)$ yang yang aktif dan 13 orang $(76,5 \%)$ tidak aktif. Hasil penelitian ini menunjukan bahwa persentase tertinggi untuk kader yang aktif terdapat pada kader yang mendapatkan dukungan penyelenggaraan posyandu yaitu sebesar $74,4 \%$.

Hasil penelitian ini menunjukkan terdapat hubungan antara dukungan penyelenggaraan posyandu dengan keaktifan kader posyandu di 
Desa Pengadegan wilayah kerja Puskesmas I Wangon. Hal ini dapat dilihat dari nilai $X^{2}$ hitung (ChiSquare) yang dihasilkan sebesar $13,146 X^{2}{ }_{\text {hitung }}>X^{2}$ tabel. Nilai $P$-value sebesar 0,000 , yang berarti nilai $P$-value $<\alpha 0,05$. Berdasarkan hasil tersebut dapat disimpulkan secara statistik terdapat hubungan antara dukungan penyelenggaraan posyandu dengan keaktifan kader posyandu dengan nilai contingency coefficient yang dihasilkan sebesar 0,424 artinya hubungan antara dukungan penyelenggaraan posyandu dengan keaktifan kader dalam kategori sedang.

Desa yang memiliki kepala desa yang selalu memberikan dukungan setiap pelaksanaan kegiatan posyandu juga menyebabkan kinerja dan kelestarian posyandu lebih baik dibandingkan dengan desa yang kepala desanya tidak memberikan dukungan. Dukungan tersebut dapat berupa pemberian pemberian tugas yang selalu dimonitor dan disupervisi, selalu memberitahukan mana yang benar dan mana yang salah dalam supervisi, dan mempertimbangkan kemampuan kader sebelum memberi tugas, dalam memberi tugas pada kader selalu ada imbalan apapun bentuknya baik itu imbalan material ataupun hanya ucapan terima kasih, bila kader mendapat tugas ketempat lain akan mendapatkan uang transport, kesejahteraan kader selalu menjadi perhatian kepala desa, kebiasaan kepala desa untuk melakukan peninjauan terhadap pelaksanaan kegiatan posyandu.

Masyarakat bukan hanya perlu pengetahuan dan sikap positif, untuk berperilaku sehat, melainkan diperlukan seperti dukungan teman sebaya, orang tua, para tokoh masyarakat, tokoh agama, para petugas kesehatan, dan dari pemerintah. Dukungan tokoh masyarakat dan tokoh agama setempat juga mempunyai pengaruh di masyarakat. Selanjutnya, tokoh agama ini dapat menjembatani antara pengelola program kesehatan dengan masyarakat. Pada masyarakat seperti di Indonesia ini, tokoh masyarakat dan tokoh agama merupakan panutan perilaku masyarakat yang sangat signifikan. Oleh karena itu, apabila tokoh masyarakat dan tokoh agama memiliki perilaku sehat, maka akan mudah ditiru oleh anggota masyarakat yang lain. Bentuk kegiatan mencari dukungan sosial ini antara lain dengan mengadakan berbagai pelatihan para tokoh agama dan tokoh masyarakat, seminar, loka karya, penyuluhan dan sebagainya. Dukungan dari tokoh agama tersebut sangat berperan penting dalam memotivasi perilaku seorang kader untuk aktif dalam kegiatan posyandu (Notoatmodjo, 2014).

Hasil penelitian ini sesuai dengan penelitian yang dilakukan oleh Wirapuspita (2013) yang menyatakan bahwa ada hubungan yang berarti antara dukungan keluarga dan masyarakat dengan keaktifan kader posyandu kader posyandu yang mendapat dukungan akan aktif di kegiatan Posyandu.

\section{SIMPULAN}

Keaktifan kader dalam kegiatan posyandu berhubungan dengan semua faktor yang diteliti yaitu pengetahuan kader, pekerjaan, motivasi kader, dan dikungan penyelenggaraan posyandu. Kader yang tinggi persentase keaktifannya merupakan kader dengan tingkat pengetahuan seputar posyandu yang baik atau tinggi, tidak bekerja, memiliki motivasi yang tinggi dan mendapat banyak dukungan untuk proses penyelenggaraan posyandu.

Terdapat berbagai cara yang dapat dilakukan oleh beberapa pihak untuk membantu dalam meningkatkan keaktifan kader adalah dengan meningkatkan pula faktor yang berhubungan dengan keaktifan kader tersebut misalnya dengan meningkatkan pengetahuan kader tentang posyandu melaluipemberian pembinaan kepada kader posyanduyang dilakukan oleh tenaga kesehatan wilayah puskesmas setempat dan refreshing kader secara berkesinambungan setiap 6 bulan sekali, dengan topik sekurang-kurangnya 5 program posyandu, yaitu kesehatan ibu dan anak, keluarga berencana, imunisasi, gizi, serta pencegahan dan penanggulangan diare.

Upaya lainnya yang dapat dilakukan selain tersebut diatas adalah dengan membuat suatu penghargaan yang diberikan oleh pemerintah daerah pada kader berprestasi dan aktif, misalnya dengan pemberian piagam penghargaan yang bertujuan meningkatkan motivasi kader dalam kegiatan posyandu. Untuk pemantauan kondisi darikeaktifan kader dalam kegiatan posyandu sebaiknya ditinjau secara berkalaoleh penanggung jawab promosi kesehatan wilayah Puskesmas setempat pada setiap tahun sehingga apabila terdapat penurunan langsung dievaluasi penyebabnya dan dapat dibuat perencanaannya untuk mempebaiki kondisi tersebut oleh puskesmas dan berbagai pihak terkait lainnya dengan memperhatikan faktor yang berhubungan dengan keaktifan kader posyandu.

\section{DAFTAR PUSTAKA}

Fadli, Latief, A. and Adriani (2013) 'Faktor - faktor yang berhubungan dengan kinerja kader Posyandu di Puskesmas Bungoro Kabupaten Pangkep', Jurnal IImiah Kesehatan, 3(2), pp. 91-97.

Happinasari, O. and Suryandari, A. E. (2016) 'Jurnal IImu Kebidanan dan Kesehatan (Journal of Midwifery Science and Health)', Jurnal IImu Kebidanan dan Kesehatan, 7(2), pp. 81-90. Available

at: http://akbidbup.ac.id/jurnal/VOL5NO1_6.pdf.

Husniyawati, Y. R. and Wulandari, R. D. (2016) 'Analisis Motivasi Terhadap Kinerja Kader Posyandu Berdasarkan Teori Victor Vroom', Jurnal Administrasi Kesehatan Indonesia, 4(2), pp. 126-135. doi: http://dx.doi.org/10.20473/jaki.v4i2.2016.126135.

Ilham, I. and Agistina (2013) 'Hubungan Pengetahuan, Pelatihan dan Motivasi Kader dengan Kinerja kader Posyandu di Wilayah Kerja Puskesmas Lisu Kecamatan Tanete Riaja Kabupaten Barru', Jurnal IImiah Kesehatan, 3, pp. 84-90. 
Kementerian Kesehatan RI (2011) Pedoman Umum Pengelolaan Posyandu, Kementerian Kesehatan RI. doi: 362.11.Ind P.

Kesehatan, D. (2012) 'Kabupaten Banyumas Tahun 2012', pp. 1-59. Available at: www.depkes.go.id/.../profil/PROFIL_KAB_K OTA_2013/3302_Jateng_Kab_Banyum

Kontesa, M. and Mistuti (2013a) 'Faktor-Faktor Yang Berhubungan Dengan Kinerja Kader Posyandu Di Wilayah Kerja Puskesmas Air Dingin Kecamatan Koto Tangah Kota Padang Tahun 2013', Jurnal STIKES Mercubaktijaya, 5(1), pp. 1-12. Available at: journal.mercubaktijaya.ac.id/downlotfile.php? file $=6 \mathrm{~d}$.pdf.

Kontesa, M. and Mistuti (2013b) 'Faktor-Faktor Yang Berhubungan Dengan Kinerja Kader Posyandu Di Wilayah Kerja Puskesmas Air Dingin Kecamatan Koto Tangah Kota Padang Tahun 2013', Jurnal STIKES Mercubaktijaya, pp. 1-12. Available at: journal.mercubaktijaya.ac.id/downlotfile.php? file $=6 \mathrm{~d}$. .pdf.

Legi, N. N. et al. (2015) 'Faktor Yang Berhubungan Dengan Keaktifan Kader Posyandu Di Wilayah Kerja Puskesmas Ranotana Weru',
Gizido, 7(2), pp. 429-436. Available at: download.portalgaruda.org.

Prang, R., Pangemanan, J. M. and Tilaar, C. (2013) Faktor-Faktor Yang Berhubungan Dengan Keaktifan Kader Posyandu Di Wilayah Kerja Puskesmas Tareran Kecamatan Tareran Kabupaten Minahasa Selatan. Universitas Sam Ratulangi. Manado. Available at: http://fkm.unsrat.ac.id.

Sistiarani, C., Nurhayati, S. and -, S. (2013) 'PERAN KADER DALAM PENGGUNAAN BUKU KESEHATAN IBU DAN ANAK', Jurnal Kesehatan Masyarakat, 8(2), pp. 99-105. doi: ISSN 1858-1196.

Wijaya, I. M. K. (2013) 'Jurnal Kesehatan Masyarakat', Jurnal Kesehatan Masyarakat, 8(2), pp. 119-127. doi: ISSN 1858-1196.

Wirapuspita, R. (2013) 'Insentif Dan Kinerja Kader Posyandu', Jurnal Kesehatan Masyarakat, 9(1), pp. 58-65. Available at: http://journal.unnes.ac.id/nju/index.php/kema s/article/view/2831. 